\title{
Plant Glycan
}

National Cancer Institute

\section{Source}

National Cancer Institute. Plant Glycan. NCI Thesaurus. Code C128564.

An oligosaccharide modifying a protein in plant cells. 